\title{
UJI POTENSI TABIR SURYA EKSTRAK ETANOL DAUN TENGGEK BURUNG (Euodia redlevi) SECARA IN VITRO
}

\author{
Musyirna Rahmah Nasution ${ }^{1 *}$, ${\text { Afrida } \text { Yeti }^{1} \text {, Bella Ardhiyati }}^{1}$ \\ ${ }^{I}$ Sekolah Tinggi Ilmu Farmasi Riau \\ email : musyirnarahmah@stifar-riau.ac.id
}

\begin{abstract}
Tenggek burung leaf (Euodia redlevi) is traditionally used to treat high blood pressure, improve blood circulation, prevent premature aging, treat diabetes mellitus and provide a fitness effect. The leaves of tenggek burung contain phenolic compounds which have sunscreens. The purpose of this study was to determine the sunscreen activity in ethanol extracts of tenggek burung leaves using spectrophotometric methods. Sunscreen activity testing is done by determining the percentage value of erythema transmission (\% Te), pigmentation transmission (\% Tp), and Sun Protection Factor (SPF) using a microplate reader. Based on the results of ethanol extract of tenggek burung leaf (Euodia redlevi) showed good sunscreen activity at a concentration of $250 \mathrm{ppm}$ with $\% \mathrm{Te}$ value of $0.4252 \%$ (Sunblock), \% Tp value of $0.3150 \%$ (Sunblock) and Sun Protection value Factor (SPF) value 21,624 (ultra protection).
\end{abstract}

Keywords: Extract, Ethanol, Tenggek burung leaf, Sunscreen

\begin{abstract}
ABSTRAK
Daun tenggek burung (Euodia redlevi) secara tradisional digunakan untuk mengobati tekanan darah tinggi, melancarkan peredaran darah, mencegah penuaan dini, mengobati diabetes mellitus serta memberikan efek kebugaran.Daun tenggek burung merupakan salah satu tumbuhan obat yang mengandung diketahui mengandung senyawa fenolik yang berpotensi sebagai tabir surya.Tujuan dari penelitian ini untuk mengetahui aktivitas tabir surya pada ekstrak etanol daun tenggek burung dengan metode spektrofotometri.Pengujian aktivitas tabir surya dilakukan dengan menentukan nilai persentase Transmisi eritema (\%Te), Transmisi pigmentasi (\%Tp), dan Sun Protection Factor (SPF) menggunakan microplate reader. Berdasarkan hasil pengujian ekstrak etanol daun tenggek burung (Euodia redlevi) menunjukan aktivitas tabir surya yang baik pada konsentrasi $250 \mathrm{ppm}$ dengan nilai \%Te sebesar 0,4252\% (Sunblock), nilai \%Tp sebesar 0,3150\% (Sunblock) dan nilai Sun Protection Factor (SPF) 21,624 (proteksi ultra).
\end{abstract}

Kata Kunci: Ekstrak, Etanol, Tenggek Burung, Tabir Surya

\section{PENDAHULUAN}

Secara alami, kulit memiliki mekanisme pertahanan terhadap efek toksik dari paparan sinar matahari, seperti pengeluaran keringat, pembentukan melanin, dan penebalan stratum corneum.Akan tetapi, pada penyinaran matahari terjadi secara berlebihan, jaringan epidermis kulit tidak cukup mampu melawan efek negatif tersebut, sehingga dapat menyebabkan eritema dan sunburn (kulit terbakar), dan dapat menimbulkan perubahan degenerasi pada kulit (penuaan dini) dan kanker kulit (Wihelmina, 2011).

Berbagai cara dapat dilakukan untuk mengatasi pengaruh buruk sinar matahari, salah satunya dengan menggunakan sediaan tabir surya. Tabir surya merupakan suatu sediaan yang secara fisik atau kimia dapat menghambat penetrasi sinar UV kedalam kulit. Penggunaan $t$ 
surya terus bertambah sejak dekade terakhir oleh karena kesadaran akan bahaya nya sinar ultraviolet yang ditimbulkan. Selain tabir surya dari bahan sintetis, tabir surya alami juga dapat diperoleh dari bahan alam.Mambro dan Fonseca (2005), menyatakan bahwa diantara berbagai macam senyawa fenolik, flavonoid diduga komponen yang dapat menangkal radikal induksi ultraviolet (UV) dan memberikan efek perlindungan terhadap radiasi UV dengan menyerap sinar UV.Tabir surya dapat menyerap sedikitnya $85 \%$ sinar matahari pada panjang gelombang 290-320 $\mathrm{nm}$ untuk UV-B tetapi dapat meneruskan sinar pada panjang gelombang lebih dari $320 \mathrm{~nm}$ untuk UV-A (Suryanto, 2012). Oleh karena itu dibutuhkan tabir surya yang dapat melindungi kulit dari bahaya radiasi sinar matahari.

Salah satu tumbuhan yang mengandung senyawa fenolik dan senyawa flavonoid adalah tanaman daun tenggek burung (Euodia redlevi).Dikalangan masyarakat pucuk daun tenggek burung (Euodia redlevi)dimakan sebagai lalapan, rasanya enak dan sedikit kelat. Daun tenggek burung (Euodia redlevi)juga berkhasiat sebagai pengobatan tekanan darah tinggi, melancarkan peredaran darah, mencegah penuaan dini, mengobati penyakit diabetes mellitus, memberikan efek kebugaran tubuh serta mampu membantu wanita yang selesai bersalin terutama untuk mengecilkan Rahim (Karim et al, 2011).

Nasution dan Ardiyati (2019) melaporkan bahwa ekstrak etanol daun tenggek burung (Euodia redlevi)tua segar menghasilkan metabolit sekunder seperti fenolik dan terpenoid, mendapatkan hasil total fenolik ekstrak etanol daun tenggek burung (Euodia redlevi) tua segar sebesar 0,676 $\mu \mathrm{g}$ $\mathrm{GAE} / \mathrm{mg}$ ekstrak dan memiliki aktivitas antioksidan $\mathrm{IC}_{50}$ sebesar $179,827 \mu \mathrm{g} / \mathrm{mL}$. Sedangkan pada ektrak etanol daun tenggek burung (Euodia redlevi) tua kering mendapatkan hasil total fenolik yang lebih kecil dari ekstrak etanol daun tenggek burung (Euodia redlevi) tua segar sebesar 0,594 $\mu \mathrm{g} \mathrm{GAE} / \mathrm{mg}$ dan memiliki aktivitas antioksidan $\mathrm{IC}_{50}$ sebesar $224,752 \mu \mathrm{g} / \mathrm{mL}$.

Berdasarkan uraian diatas dan belum adanya publikasi ilmiah tentang potensi tabir surya dari daun tenggek burung, maka pada penelitian ini bertujuan untuk menentukan aktivitas tabir surya dari ekstrak etanol daun tenggek burung yang meliputi nilai transmisi eritema, transmisi pigmentasi dan nilai SPF (Sun Protection Factor).

\section{METODE}

\section{Alat dan Bahan}

Alat yang digunakan dalam penelitian ini adalah timbangan analitik (Shimadzu Auw 220), 96 well clear polystyrene microplate, microplate reader (Berthold LB 941), pipet mikro (Socorex), plat tetes,pipet tetes, beker glass, labu ukur, kaca arloji, dan corong.

Bahan yang digunakan adalah ekstrak etanol daun tenggek burung tua segar (Euodia redlevi), etanol pa, kloroform, kloroform amoniak, logam magnesium ( $\mathrm{Mg}$ ), larutan besi (III) klorida $\left(\mathrm{FeCl}_{3}\right)$, asam sulfat $\left(\mathrm{H}_{2} \mathrm{SO}_{4}\right) 2 \mathrm{~N}$, asam sulfat pekat, asetat anhidrida, pereaksi Lieberman-Burchard, dan pereaksi Mayer.

\section{Pengujian Skrining Fitokimia Ekstrak Etanol}

Uji pendahuluan kandungan metabolit sekunder dilakukan terhadap ekstrak etanol daun tenggek burung (Euodia redlevi), dilakukan dengan cara menambahkan masing-masing $5 \mathrm{~mL}$ air suling dan $5 \mathrm{~mL}$ kloroform (1:1) pada ekstrak kental didalam tabung reaksi, lalu dikocok kuat dan dibiarkan beberapa saat hingga terbentuk dua lapisan. Lapisan air digunakan untuk uji senyawa flavonoid, fenolik, dan saponin.Lapisan kloroform digunakan untuk uji senyawa terpenoid, dan steroid.Sedangkan untuk uji alkaloid memiliki prosedur tersendiri (Harborne, 1996).

1. Uji Fenolik

Beberapa tetes lapisan air di masukkan dalam plat tetes lalu ditambah 1-2 tetes larutan $\mathrm{FeCl}_{3}$

$1 \%$. Apabila terbentuk warna biru/hijau, berarti terdapat senyawa fenolik.

2. Uji Flavonoid 
Beberapa tetes lapisan air di masukkan dalam plat tetes ditambah 1-2 butir logam magnesium dan 1-2 tetes asam klorida $(\mathrm{HCl})$ pekat. Apabila terbentuk warna kuning atau jingga hingga kemerahan menandakan adanya senyawa flavonoid.

3. Uji Saponin

Beberapa tetes lapisan air di masukkan dalam tabung reaksi lalu dikocok kuat.Apabila terbentuknya busa yang tidak segera hilang apabila didiamkan selama \pm 15 menit menunjukkan adanya senyawa saponin.

4. Uji Terpenoid dan Steroid

Lapisan kloroform disaring melalui pipet tetes yang diberi kapas dan norit pada ujungnya. Hasil saringan di pipet 2-3 tetes dan dibiarkan mengering pada plat tetes. Setelah kering ditambahkan pereaksi Liebermann-Burchard (2 tetes asam asetat anhidrat dan 1 tetes asam sulfat pekat).Apabila terbentuk warna merah menandakan adanya terpenoid dan warna hijau atau biru menandakan adanya steroid.

5. Uji Alkaloid

Sampel ekstrak etanol daun tenggek burung (Euodia redlevi) sebanyak $5 \mathrm{~mL}$ dimasukkan dalam tabung reaksi ditambahkan $5 \mathrm{~mL}$ kloroform, dan $5 \mathrm{~mL}$ larutan kloroform-amoniak, kemudian dikocok. Lalu tambahkan 2 tetes asam sulfat $2 \mathrm{~N}$, kemudian ambil lapisan asam (atas) dan tambahkan 1-2 tetes pereaksi Mayer.Apabila terbentuk endapan putih atau merah dengan pereaksi Mayer menandakan adanya alkaloid.

\section{Penentuan Aktivitas Tabir Surya Daun Tenggek Burung (Euodia redlevi)}

1. Persiapan Larutan

Sejumlah $10 \mathrm{mg}$ ekstrak etanol daun tua segar tenggek burung (Euodia redlevi) dilarutkan dalam $10 \mathrm{~mL}$ larutan etanol pa sehingga diperoleh konsentrasi $1000 \mathrm{ppm}$, kemudian pengujian dilakukan pada konsentrasi 500 ppm, 250 ppm, 125 ppm, 62,5 ppm, 31,25 ppm, 15,625 ppm dan 7,8125 ppm.

2. Pengukuran Absorban

Pada baris A dimasukan sebanyak $200 \mu \mathrm{L}$ larutan konsentrasi 1000 ppm. Lalu, sebanyak 100 $\mu \mathrm{L}$ etanol pa dimasukan kedalam masing-masing sumur baris B-H.Kemudian dipipet $100 \mu \mathrm{L}$ baris A dimasukan ke baris B dan dihomogenkan. Kemudian baris B dipipet $100 \mu \mathrm{L}$ dimasukan ke baris $\mathrm{C}$ dan dilakukan sampai baris H. Baris $\mathrm{H}$ dipipet $100 \mu \mathrm{L}$ lalu dibuang.Dilakukan pengujian dengan 3 kali pengulangan. Sehingga diperoleh konsentrasi larutan uji $1000 \mathrm{ppm}(\mu \mathrm{g} / \mathrm{mL}), 500 \mathrm{ppm}(\mu \mathrm{g} / \mathrm{mL}), 250 \mathrm{ppm}(\mu \mathrm{g} / \mathrm{mL}), 125 \mathrm{ppm}(\mu \mathrm{g} / \mathrm{mL}), 62,5$ ppm $(\mu \mathrm{g} / \mathrm{mL}), 31,25 \mathrm{ppm}(\mu \mathrm{g} / \mathrm{mL}), 15,625 \mathrm{ppm}(\mu \mathrm{g} / \mathrm{mL})$ dan 7,8125 ppm $(\mu \mathrm{g} / \mathrm{mL})$. Kemudian dilakukan pengujian dengan panjang gelombang daerah UV B dari $290 \mathrm{~nm}$ sampai $320 \mathrm{~nm}$ dengan selisih jarak $5 \mathrm{~nm}$. Pada daerah UV A diuji dari panjang gelombang $325 \mathrm{~nm}$ sampai $370 \mathrm{~nm}$ dengan selisih jarak $5 \mathrm{~nm}$.

\section{Analisa Data}

Larutanuji 1000 ppm, 500 ppm, 250 ppm, 125 ppm, 62,5 ppm, 31,25 ppm, 15,625 ppm dan $7,8125 \mathrm{ppm}$, diukur transmitannya pada panjang gelombang 290-320nm setiapinterval5 nmuntuknilai\%Tedanpanjang gelombang325-370nmsetiapinterval5nmuntuknilai\%Tp.Persentase transmisi eritema dan persentase transmisi pigmentasi dihitung menggunakan rumus, (Whenny et al, 2015) :

$$
\begin{aligned}
& \% \mathrm{Te}=\frac{E e}{\sum F e}=\frac{\sum(T \times F e)}{\sum F e} \\
& \% \mathrm{Tp}=\frac{E p}{\sum F p}=\frac{\sum(T x F p)}{\sum F p}
\end{aligned}
$$


Keterangan:

$\mathrm{T} \quad=$ Transmisi

$\mathrm{Fe} \quad=$ Flukseritemapadapanjanggelombangtertentu

Ee =Banyaknya flukseritema yang diteruskan oleh tabirsurya

$\mathrm{Fp} \quad=$ Fluks pigmentasipada panjang gelombang tertentu

Ep =Banyaknyaflukspigmentasiyangditeruskanoleh tabirsurya

Pengukuran nilaiSun Protection Factor (SPF)

Perhitungan nilai SPF mengikuti persamaan Mansur (1986). Persamaannya adalah sebagai berikut :

$$
\mathrm{SPF}=C F \times \sum_{290}^{320} E E(\lambda) x I(\lambda) x A(\lambda)
$$

Keterangan :

$\mathrm{CF}=$ FaktorKoreksiyangbernilai(10)

$\mathrm{EE}=$ Efek eritmogenik radiasi pada panjang gelombang

I =Spektrumsimulasisinarsurya

Abs =NilaiAbsorbansiproduktabirsurya

\section{HASIL DAN PEMBAHASAN}

Penelitian ini menggunakan ekstrak etanol daun tenggek burung (Euodia redlevi) yang memiliki metabolit sekunder menarik yaitu fenolik dan terpenoid.Menurut Pontoan (2016) Senyawa fenolik merupakan senyawa aktif antioksidan, adanya korelasi antara antioksidan dengan aktivitas tabir surya, semakin tinggi aktivitas antioksidan semakin tinggi aktivitas tabir surya.Senyawa fenolik dapat berperan sebagai tabir surya untuk mencegah efek yang merugikan akibat radiasi sinar UV pada kulit karena antioksidan sebagai fotoprotektif (Svobodova et al., 2003).

Sejumlah $10 \mathrm{mg}$ ekstrak etanol daun tua segar tenggek burung (Euodia redlevi) dilarutkan dalam $10 \mathrm{~mL}$ larutan etanol pa sehingga diperoleh konsentrasi $1000 \mathrm{ppm}$, kemudian pengujian dilakukan pada konsentrasi 500 ppm, 250 ppm, 125 ppm, 62,5 ppm, 31,25 ppm, 15,625 ppm dan 7,8125 ppm. Pengukuran dilakukan pada panjang gelombang 290-320nm setiapinterval5 nmuntuknilai\%Te, SPF danpanjang gelombang325-370nmsetiapinterval5nmuntuknilai\%Tp.

Berdasarkan penelitian yang telah dilakukan mengenai penentuan nilai Sun Protection Factor (SPF)ekstrak etanol daun tenggek burung (Euodia redlevi)diperoleh hasil sebagai berikut : 
Tabel I.Hasil Skrining Fitokimia Ekstrak Etanol Daun Tenggek Burung (Euodia redlevi)

\begin{tabular}{ccc}
\hline Pereaksi & Hasil Pengamatan & Keterangan \\
\hline Pereaksi Mayer & Tidak terbentuk endapan putih & Alkaloid(-) \\
$\begin{array}{c}\text { Lapisan air+logam } \mathrm{Mg}+\mathrm{HCl} \\
\text { pekat }\end{array}$ & $\begin{array}{c}\text { Tidak terbentuk larutan berwarna } \\
\text { kuning orange }- \text { merah }\end{array}$ & Flavonoid(-) \\
Lapisan air+FeCl & Terbentuk larutan hijau & Fenolik(+) \\
$\begin{array}{c}\text { Lapisan } \\
\text { air kocok kuat } \\
\text { Liebermann Buchard } \\
\text { Liebermen Burchard }\end{array}$ & Tidak terbentuk busa & Saponin(-) \\
\hline
\end{tabular}

Ket: (-) = Negatif (tidak mengandung metabolit sekunder)

$(+)=$ Positif (mengandung metabolit sekunder)

Penentuan aktivitas tabir surya ini dilakukan dengan menghitung nilai transmisi eritema (\%Te), transmisi pigmentasi (\%Tp) dan SPF (Sun Protection Factor).Penentuan \%Te dan SPF (Sun Protection Factor) adalah untuk menunjukan efektivitas tabir surya terhadap UV-B, sedangkan $\% \mathrm{Tp}$ ditentukan melihat efektivitas tabir surya terhadap UV-A.Senyawafenolik merupakankomponenyang dapatmenangkalradikal induksiultraviolet(Yanuartietal.2017).

Persentase transmisi eritema (\% Te) adalah nilai yang menggambarkan kemampuan suatu senyawa kimia dalam memproteksi kulit dari sinar ultraviolet (UV-B) 290-320 nm yang dapat menyebabkan eritema atau kemerahan (Hasanah et al, 2015).Hasil yang didapat pada pengukuran $\%$ Te pada ekstrak etanol daun tenggek burung (Euodia redlevi) dengankonsentrasi1000, 500, 250 ppm dengan nilai \%Te 0,$0355 ; 0,0607 ; 0,4252$ yang memiliki kategori sunblock, sedangkan pada konsentrasi 125 ppm dengan nilai 3,9292 memiliki kategori proteksi ekstra. Pada konsentrasi 62,$5 ; 31,25 ; 15,625 ; 7,8125$ dengan nilai $\%$ Te 15,$4475 ; 27,5989 ; 36,0813 ; 44,5214$ yang memiliki kategori fast tanning.

Persentase transmisi pigmentasi (\% Tp) menggambarkan kemampuan senyawa untuk memproteksi kulit dari sinar UV A 320-370 nm yang dapat menyebabkan kulit menjadi gelap (Hasanah et al, 2015).Pada ekstrak etanol daun tenggek burung (Euodia redlevi)hasil \% Tp pada konsentrasi 1000; 500; 250; 125 ppm dengan nilai \% Tp 0,1411; 0,2441; 0,9315\%; 24,8746\% yang merupakan kategori Sunblock, sunblock karena berada padakisaran 3-40.Sunblock merupakan aktivitas tabir surya yang paling terbaik, karna memberikan perlindungan pada kulit secara total dari sinar UV-A dan UV-B, sehingga kulit terlindung dari eritema dan pigmentasi. Pada konsentrasi 62,$5 ; 31,25 ; 15,625$ dan 7,8125 ppm dengan nilai \%Tp sebesar 45,5506; 58,8241; 65,4435 dan 72,2259 yang memiliki kategori fast tanning. Fast tanning dalam pengertian tabir surya adalah kemampuan suatu molekul kimia tabir surya yang dapat menggelapkan kulit secara cepat tanpa menimbulkan eritema dengan memberikan transmisi penuh pada radiasi UV A untuk memberikan efek penggelapan yang maksimal (Whenny et al, 2015). 
JOPS (Journal Of Pharmacy and Science)

Vol.4, No.2, Bulan Juni 2021, Hal. 44-51

p-ISSN: 2622-9919; e-ISSN: 2615-1006

Tabel II. Aktivitas tabir surya Ekstrak Etanol Daun Tenggek Burung (Euodia redlevi)

\begin{tabular}{|c|c|c|c|}
\hline $\begin{array}{c}\text { Konsentrasi } \\
(\mu \mathrm{g} / \mathrm{mL})\end{array}$ & SPF & $\% \mathrm{Te}$ & $\% \mathbf{T p}$ \\
\hline 1000 & $\begin{array}{c}32,303 \\
\text { Proteksi ultra }\end{array}$ & $\begin{array}{l}0,0355 \pm 0,0062 \\
\text { Sunblock }\end{array}$ & $\begin{array}{c}0,1411 \pm 0,0012 \\
\text { Sunblock }\end{array}$ \\
\hline 500 & $\begin{array}{c}30,026 \\
\text { Proteksi ultra }\end{array}$ & $\begin{array}{c}0,0607 \pm 0,0174 \\
\text { Sunblock }\end{array}$ & $\begin{array}{c}0,2441 \pm 0,0314 \\
\text { Sunblock }\end{array}$ \\
\hline 250 & $\begin{array}{c}21,624 \\
\text { Proteksi ultra }\end{array}$ & $\begin{array}{l}0,4252 \pm 0,011 \\
\text { Sunblock }\end{array}$ & $\begin{array}{l}0,9315 \pm 0,0107 \\
\text { Sunblock }\end{array}$ \\
\hline 125 & $\begin{array}{c}12,409 \\
\text { Proteksi maksimal }\end{array}$ & $\begin{array}{l}3,9292 \pm 0,0219 \\
\text { Proteksi Ekstra }\end{array}$ & $\begin{array}{c}24,8746 \pm 0,0179 \\
\text { Sunblock }\end{array}$ \\
\hline 61,5 & $\begin{array}{c}6,867 \\
\text { Proteksi Ekstra }\end{array}$ & $\begin{array}{c}15,4475 \pm 0,0059 \\
\text { Fast tanning }\end{array}$ & $\begin{array}{c}45,5506 \pm 0,0031 \\
\text { Fast tanning }\end{array}$ \\
\hline 31,25 & $\begin{array}{c}4,548 \\
\text { Proteksi Sedang }\end{array}$ & $\begin{array}{c}27,5989 \pm 0,0059 \\
\text { Fast tanning }\end{array}$ & $\begin{array}{c}58,8241 \pm 0,0043 \\
\text { Fast tanning }\end{array}$ \\
\hline 15,6 & $\begin{array}{c}3,482 \\
\text { Proteksi minimal }\end{array}$ & $\begin{array}{c}36,0813 \pm 0,0183 \\
\text { Fast tanning }\end{array}$ & $\begin{array}{c}65,4435 \pm 0,0178 \\
\text { Fast tanning }\end{array}$ \\
\hline 7,81 & $\begin{array}{c}2,658 \\
\text { Proteksi minimal }\end{array}$ & $\begin{array}{c}44,5214 \pm 0,0132 \\
\text { Fast tanning }\end{array}$ & $\begin{array}{l}\text { 72,2259 } \pm 0,0054 \\
\text { Fast tanning }\end{array}$ \\
\hline
\end{tabular}

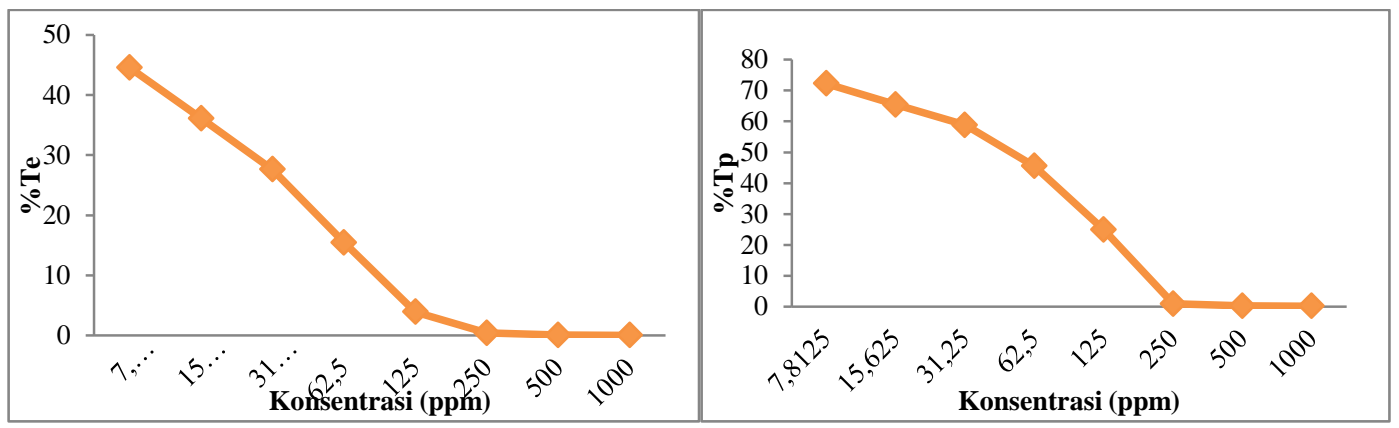

a

b

Gambar 1.Grafik \%Te (a) dan \% Tp (b) Ekstrak Etanol Daun Tenggek Burung (Euodia redlevi) 


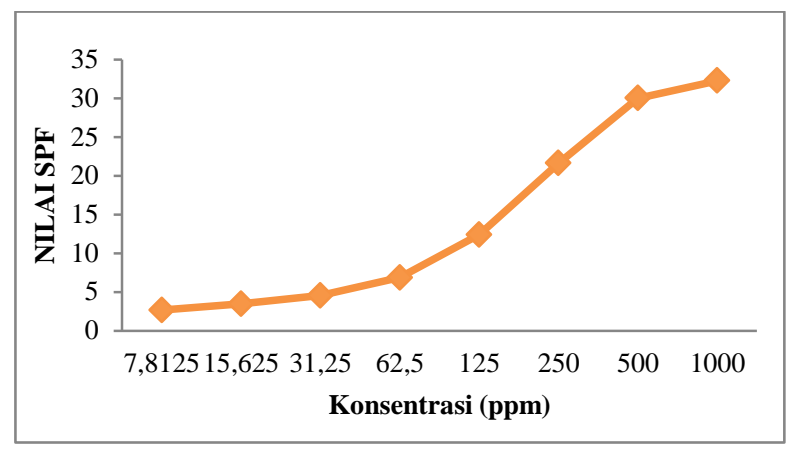

Gambar 2.Grafik SPF (Sun Protection Factor) Ekstrak Etanol Daun Tenggek Burung (Euodia redlevi)

Sun Protecting Factor (SPF) merupakan ukuran kemampuan tabir surya untuk mencegah kerusakan kulit.Tabir surya dengan SPF menyatakan lamanya kulit seseorang berada dibawah sinar matahari tanpa mengalami luka bakar, sedangkan angka SPF menyatakan berapa kali daya tahan alami kulit seseorang dilipat gandakan sehingga aman dibawah matahari tanpa terkena luka bakar (Wala et al, 2015).Berdasarkan pengukuran nilai SPF yang di dapat pada ekstrak etanol daun tenggek burung (Euodia redlevi)pada konsentrasi 1000; 500; $250 \mathrm{ppm}$ dengan nilai SPF berturut turut yaitu 32,30; 30,02; 21,62 yang memiliki kategori proteksi ultra. Pada konsentrasi 125; 62,5; 31,$25 ; 15,625 ;$ dan 7,8125 ppm dengan nilai SPF berturut-turut yaitu 12,$40 ; 6,86 ; 4,54 ; 3,48 ; 2,65$ yang memiliki kategori proteksi maksimal; proteksi ekstra; proteksi sedang; dan proteksi minimal. Semakin besar nilai SPF maka akan semakin baik pula nilai yg diberikan untuk memproteksi kulit dari sinar UV (FDA, 2003).Aktivitas tabir surya ekstrak etanol daun tenggek burung (Euodia redlevi) pada konsentrasi 1000 ppm yang termasuk kategori proteksi ultra telah mampu memberikan aktivitas tabir surya sehingga ekstrak etanol daun tenggek burung tersebut dapat dibuat sebagai sediaan tabir surya.

\section{KESIMPULAN}

Berdasarkan penelitian yang telah dilakukan, maka dapat disimpulkan bahwa aktivitas tabir surya dengan nilai \%Te, \% Tp dan SPF terbaik pada ekstrak etanol daun tenggek burung (Euodia redlevi)pada konsentrasi 250 ppm nilai \%Te sebesar 0,4252\% yang termasuk kategori Sunblock, nilai \%Tp sebesar 0,9315\% yang termasuk kategori Sunblock dan memiliki nilai SPF 21,624 yang dikategorikan Proteksi Ultra.

\section{SARAN}

Disarankan untuk mengembangkan sampel ekstrak etanol daun tenggek burung (Euodia redlevi)menjadi sediaan tabir surya.

\section{REFERENSI}

Food and Drug Administration (FDA). 2003. Guidance For Industry Photosafety Testing, Pharmacology Toxycology. Coordinating Committee in the Centre For Drug Evaluation and Research (CDER) AT the FDA.

Harborne, J.B. 1996. Metode Fitokimia Edisi II-b.Diterjemahkan oleh Kosasih Padmawinata.Penerbit.ITB. Bandung.

Hasanah, S., Islamudin, Ahmad., Laode, R., 2015, Profil Tabir Surya Ekstrak Dan Fraksi Daun Pidada Merah (Sonneratica caseolaris L.), Jurnal Sains Dan Kesehatan, 1, (4) :175-180. 
Karim, Ab. M.S., Nasouddin, S.S., Othman, M., Moh Adzahan, N., Hussin, S.R., dan Khozirah, S. 2011. Consumers Knowledge and Perception TowardsMelicope ptelefolia (Daun Tenggek Burung): A Preliminary Qualitative Study. International Food Research Journal. 18(4): $1481-1488$

Mansur, J, S., Breder, M, N, R., Mansur, M, C, A., Azulay, R, D., 1986, Determinacao do Fator de Protecao Solar por Espectrofotometria, An, Bras, Dermatol, 61 : 121-124.

Mambro, v dan fonseca M.J., 2004. Assay of Physical Stability and Antioxidant Activy of a Topical Formulation Added with Different Plant Exstracts, J. Pharmaceut. Biomed., 287295.

Nasution, M.R dan Ardhiyati, B., 2019. Total Fenolik dan Flavonoid Serta Aktivitas AntioksidanEkstrak Etanol Daun Tenggek Burung (Euodia redlevi)., Prosiding SainsTeKes Semnas MIPAKes UMRI., Vol 1. Hal 58-65.

Pontoan, J., 2016, Uji Aktivitas Antioksidan dan Tabir Surya dari Ekstrak Daun Alpukat (Persea americana M.), Indonesia Natural Research Pharmaceutical Journal, 1, (1) : 55-66.

Sugihartini, N. Optimasi Komposisi Tepung Beras dan Fraksi Etanol Daun Sendok (Plantago major L.)Dalam Formulasi Tabir Surya dengan Metode Simplex Latice Design.Skripsi. Fakultas Farmasi Universitas Ahmad Dahlan: Yogyakarta.

Svobodova, A., J. Psotova., D. Walterova. 2003. Natural Phenolics in the Prevention of UVInduced Skin Damage. Biomed.Pap.147:137-145.

Whenny., Rolan, R., Laode, R., 2015, Aktivitas Tabir Surya Ekstrak Daun Cempedak (Artocarpus champeden spreng), Jurnal Sains dan Kesehatan, 1 (4) : 154-158.

Wihelmina, Cynthya E. 2011. Pembuatan dan Penentuan Nilai SPF Nanoemulsi Tabir Surya Menggunakan Minyak kencur (Kaemferia galanga L.) sebagai Fase Minyak.Depok.

Yanuarti,R.,Nurjanah,Anwar,E.,Pratama,G. 2017.KandunganSenyawaPenangkalSinarUltraViolet dariEkstrakRumput LautEucheumacottoniidan Turbinariaconoides.Jurnal PengolahanHasilPerikananIndonesia.Bogor.BiosferaVol34,No2:51-58 